\title{
Impaired Control of L-Type Voltage-Dependent Calcium Channels in Experimental Hypertension
}

\author{
M. PINTÉROVÁ ${ }^{1,2}$, S. LÍŠKOVÁ ${ }^{1,2,3}$, Z. DOBEŠOVÁ ${ }^{1,2}$, M. BEHULIAK ${ }^{1,4}$, J. KUNES̆ $^{1,2}$, \\ J. ZICHA ${ }^{1,2}$
}

${ }^{1}$ Center for Cardiovascular Research, Prague, ${ }^{2}$ Institute of Physiology, Academy of Sciences of the Czech Republic, Prague, Czech Republic, ${ }^{3}$ Institute of Pharmacology, Faculty of Medicine, Comenius University, Bratislava, ${ }^{4}$ Institute of Pathophysiology, Faculty of Medicine, Comenius University, Bratislava, Slovak Republic

Received June 9, 2009

Accepted October 30, 2009

\begin{abstract}
Summary
Blood pressure (BP) level results from the balance of vasoconstrictors (mainly sympathetic nervous system) and vasodilators (predominantly nitric oxide and endothelium-derived hyperpolarizing factor). Most of the forms of experimental hypertension are associated with sympathetic hyperactivity and endothelial dysfunction. It is evident that nitric oxide and norepinephrine are antagonists in the control of calcium influx through L-type voltage-dependent calcium channels (L-VDCC). Their effects on L-VDCC are mediated by CGMP and CAMP, respectively. Nevertheless, it remains to determine whether these cyclic nucleotides have direct effects on L-VDCC or they act through a modulation of calcium-activated $\mathrm{K}^{+}$and $\mathrm{Cl}^{-}$channels which influence membrane potential. Rats with genetic or salt hypertension are characterized by a relative (but not absolute) NO deficiency compared to the absolute enhancement of sympathetic vasoconstriction. This dysbalance of vasoconstrictor and vasodilator systems in hypertensive animals is reflected by greater calcium influx through L-VDCC susceptible to the inhibition by nifedipine. However, when the modulatory influence of cyclic nucleotides is largely attenuated by simultaneous ganglionic blockade and NO synthase inhibition, BP of spontaneously hypertensive rats remains still elevated compared to normotensive rats due to augmented nifedipine-sensitive BP component. It remains to determine why calcium influx through L-VDCC of hypertensive rats is augmented even in the absence of modulatory influence of major vasoactive systems (sympathetic nervous system, nitric oxide).
\end{abstract}

\author{
Key words \\ L-type voltage-dependent calcium channels - Calcium-activated \\ $\mathrm{K}^{+}$and $\mathrm{Cl}^{-}$channels - Vasoactive systems - EDCF - Blood \\ pressure control $\bullet$ Isolated arteries
}

\section{Corresponding author}

J. Zicha, Institute of Physiology, Academy of Sciences of the Czech Republic, Vídeňská 1083, 14220 Prague 4, Czech Republic. Fax: +420 24106 2488. E-mail: zicha@biomed.cas.cz

\section{Introduction}

Hypertension and its target organ complications represent a great risk factor for cardiovascular health in developed societies. High blood pressure (or better said its surrogate increased systemic resistance) is caused by numerous factors ranging from altered activity of particular vasoactive systems over vascular smooth muscle (VSM) hyperreactivity up to the remodeling of resistance vessels. The balance of vasoconstrictor and vasodilator systems, which is modulated at both central and peripheral levels, is decisive for setting of vascular tone (Fig. 1). It is well known that $\mathrm{Ca}^{2+}$ influx plays a key role in vascular contraction because lasting VSM contraction can hardly be elicited in the absence of extracellular calcium. This was also documented in our previous study (Paulis et al. 2007) in which norepinephrine (NE) caused only a transient phasic contraction of isolated artery incubated in $\mathrm{Ca}^{2+}$-free medium, whereas sustained tonic contraction appeared 
only when $\mathrm{Ca}^{2+}$ was added into the incubation medium. A major part of this NE-induced tonic contraction could be abolished or prevented by nifedipine - a dihydropyridine antagonist of L-type voltage-dependent calcium channels (L-VDCC). Since tonic but not phasic contraction of NEstimulated artery can be augmented by endothelium removal (Fig. 2) or inhibition of nitric oxide (NO) synthesis, it is evident that vasodilator effects of NO are mediated by inhibition of $\mathrm{Ca}^{2+}$ influx through L-VDCC. Thus NE and NO appear to be the most prominent counterplayers in the control of nifedipine-sensitive $\mathrm{Ca}^{2+}$ influx that is responsible for actual vascular tone.

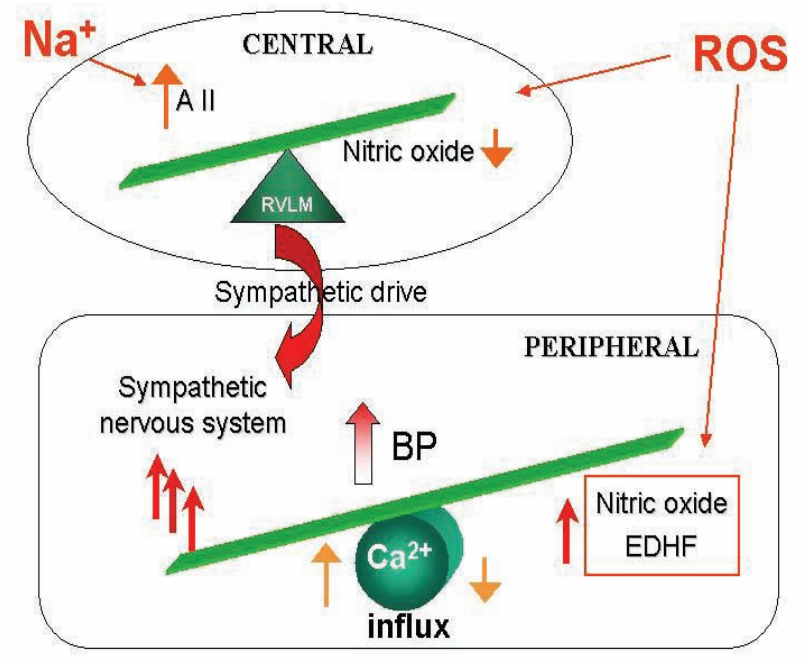

Fig. 1. The simplified scheme of major central and peripheral mechanisms regulating blood pressure through the control of sympathetic tone and calcium influx into smooth muscle of resistance vessels. A II - angiotensin II, ROS - reactive oxygen species, EDHF - endothelium-derived hyperpolarization factor, BP - blood pressure.

In most forms of experimental hypertension high blood pressure (BP) results from the dysbalance between sympathetic hyperactivity and vasodilator deficiency which is often relative rather than absolute. This could be documented in rats with genetic (hereditary hypertriglyceridemic (HTG) rats - Kuneš et al. 2002, spontaneously hypertensive (SHR) rats - Paulis et al. 2007, Hojná et al. 2007, Kuneš et al. 2008) or saltdependent forms (Dahl rats - Zicha et al. 2001, Dobešová et al. 2002) of genetic hypertension. Somewhat different type of vasoconstrictor/vasodilator dysbalance was disclosed in rats with L-NAME-induced hypertension in which severe NO deficiency was accompanied by moderate enhancement of sympathetic and angiotensindependent vasoconstriction which are also involved in the maintenance of elevated BP (Pechán̆ová et al. 2004). Our further experiments indicated that missing NO is partially replaced by vasodilator effects of endothelium-derived hyperpolarizing factor (EDHF) in order to counterbalance partially augmented effects of above mentioned vasoconstrictor systems (Fig. 3).

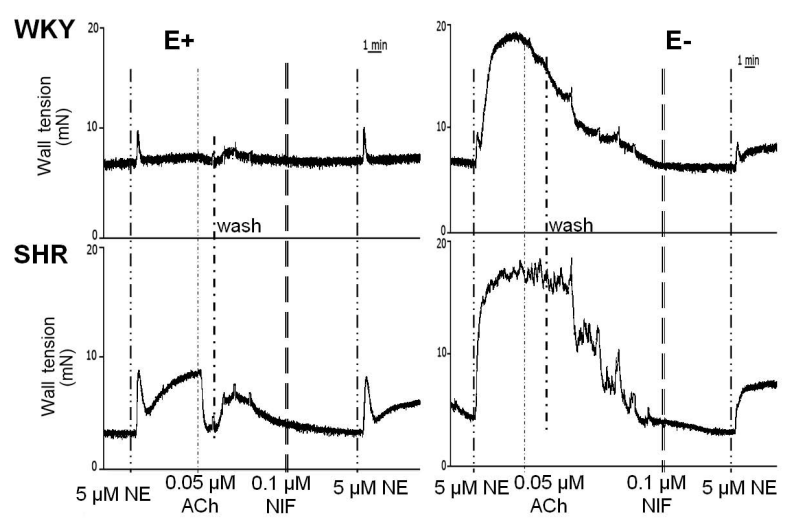

Fig. 2. Norepinephrine (NE)-induced contraction $(\mathrm{mN})$ of femoral arteries isolated from WKY (upper panels) and SHR (lower panels) with $(\mathrm{E}+)$ or without endothelium $(\mathrm{E}-)$ prior and after the addition of nifedipine (NIF). The early transient phasic NEinduced contractions of arteries with intact endothelium reflect a mobilization of internal calcium stores, whereas tonic contractions are characteristic for deendothelized arteries. Tonic NE-induced contractions are based upon $\mathrm{Ca}^{2+}$ influx mainly through voltagedependent calcium channels susceptible to the inhibition by nifedipine. Note that moderate NE-induced tonic contractions can also be seen in endothelized SHR arteries.
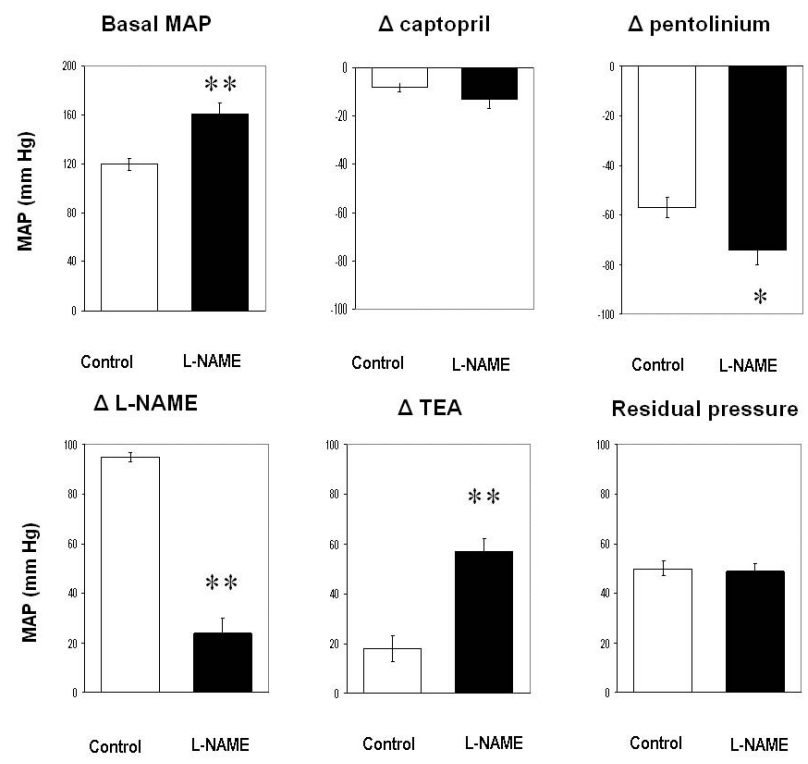

Residual pressure

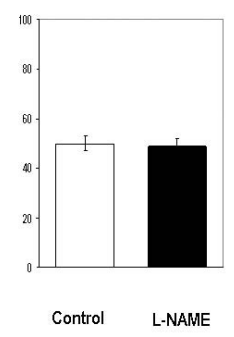

Fig. 3. Basal BP, BP changes elicited by the blockade of particular vasoactive systems and residual pressure (recorded after nitroprusside injection) in control and L-NAME-treated Wistar rats. Significant differences from untreated Wistar rats are indicated by $*$, $* *(p<0.05, p<0.01)$. Data are means \pm S.E.M. $(\mathrm{n}=10-12)$. TEA - tetraethylammonium, L-NAME $\mathrm{N}^{\mathrm{G}}$-nitro-L-arginine methyl ester. 


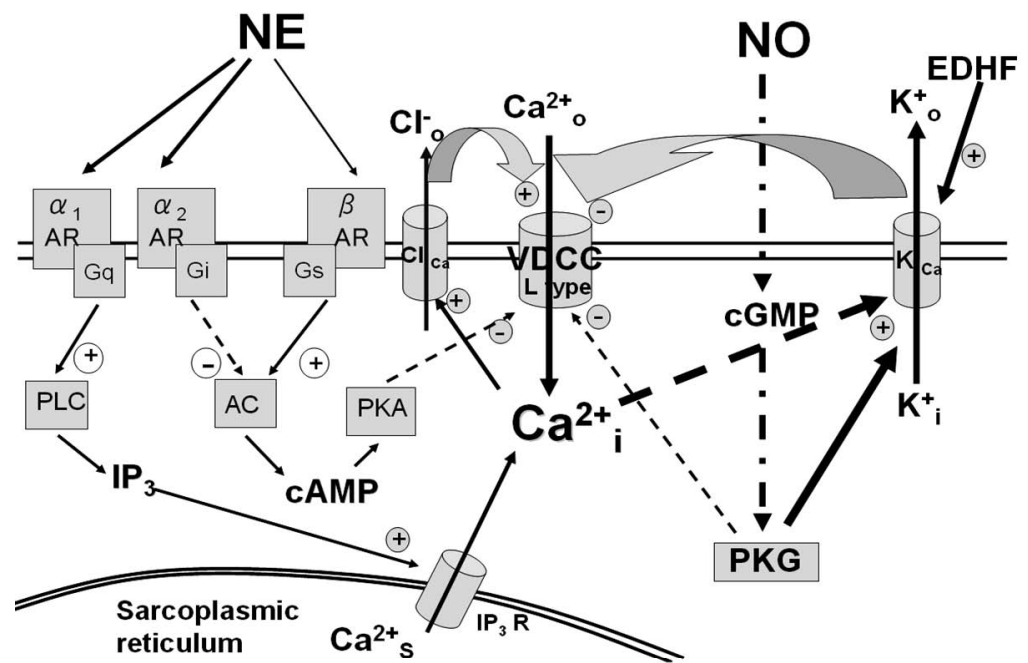

Fig. 4. The scheme of the influence of norepinephrine (NE) and nitric oxide (NO) on the control of $\mathrm{Ca}^{2+}$ influx through voltage-dependent calcium channels of $L$ type (VDCC L type) into vascular smooth muscle cells. Abbreviations: AR adrenoceptors, Gq, Gi and Gs - particular G proteins, PLC - phospholipase C, AC - adenylate cyclase, PKA and PKG - protein kinases A and G, CAMP and CGMP - cyclic adenosine and guanosine monophosphates, $\mathrm{Cl}_{\mathrm{Ca}}$ and $\mathrm{K}_{\mathrm{Ca}}-$ calcium-activated chloride and potassium channels, EDHF endothelium-derived hyperpolarization factor, $\mathrm{IP}_{3} \mathrm{R}$ - inositol triphosphate receptor.
Since increased sympathetic activity and/or decreased NO bioavailability tend to open L-VDCC (Fig. 4), it is not surprising that all so far examined forms of experimental hypertension displayed more pronounced BP reduction following the acute blockade of these calcium channels by nifedipine (Kuneš et al. 2004). As we have demonstrated in three different forms of experimental hypertension (SHR, Dahl, NO-deficient), the magnitude of nifedipine-induced BP reduction was proportional to initial (baseline) BP level (Kuneš et al. 2004). This linear relationship was present within the range of mean arterial pressure between 80 and $250 \mathrm{~mm}$ $\mathrm{Hg}$ under all experimental conditions so far investigated. This extraordinary strong biological phenomena can be disclosed in rats with developing or established hypertension as well as in rats subjected to various dietary or pharmacological antihypertensive interventions
(Fig. 5). In addition, using isolated femoral arteries we succeeded to reveal an analogous relationship between maximal NE-induced wall tension and wall tension change following nifedipine addition to incubation medium (Paulis et al. 2007).

We have demonstrated in salt hypertensive Dahl rats that there is a steeper slope of the relationship between nifedipine-induced BP changes and basal BP compared to the relationship between BP changes induced by ganglionic blocker pentolinium and basal BP (Fig. 6). This indicates a progressive augmentation of $\mathrm{Ca}^{2+}$ influx through L-VDCC with increasing blood pressure. It remains an open question whether greater $\mathrm{Ca}^{2+}$ influx in hypertensive animals results mainly from enhanced sympathetic stimulation of their resistance vessels or is also a consequence of endothelial dysfunction involving relative NO deficiency.
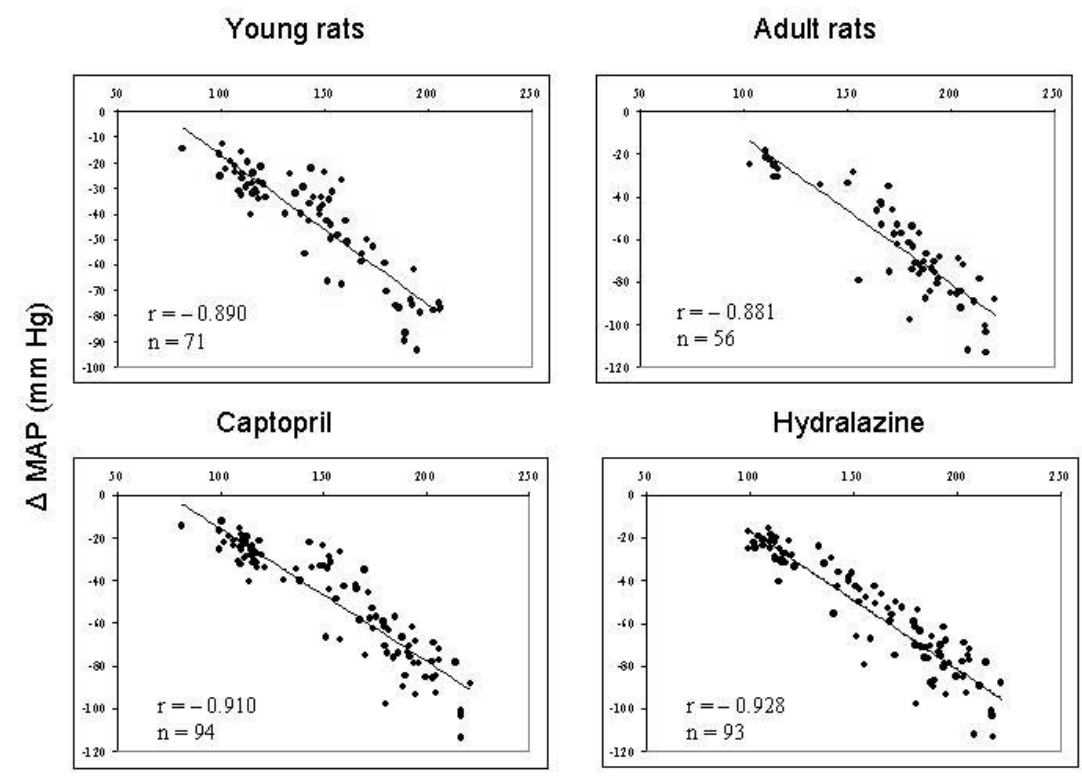

Fig. 5. The relationship of nifedipineinduced BP changes to basal BP in young and adult rats (upper panels) as well as in rats subjected either to active treatment with ACE inhibitor captopril or vasodilator hydralazine or studied after the withdrawal of these drugs (lower panels).

Basal MAP $(\mathrm{mm} \mathrm{Hg})$ 

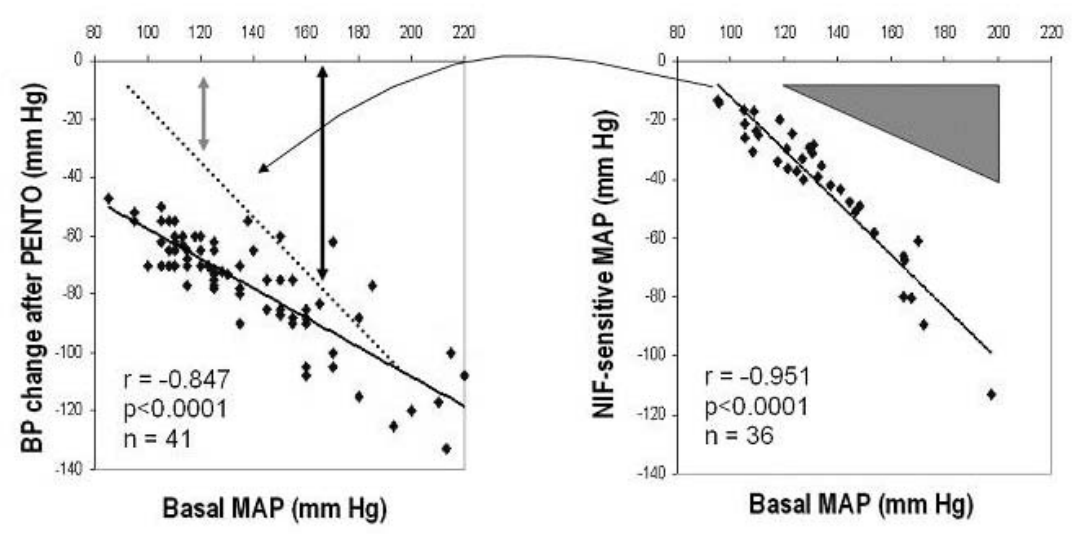

Fig. 6. The relationship of pentoliniuminduced (left panel) and nifedipineinduced (right panel) BP changes to basal $\mathrm{BP}$ in Dahl rats. The dark triangle indicates the augmentation of endothelial dysfunction and nifedipine sensitivity with increasing blood pressure. The dotted line in the left panel corresponds to the regression line depicted in the right panel. Vertical arrows (left panel) depict the contribution of nifedipine-sensitive calcium influx to sympathetic BP component in normotensive and hypertensive animals.
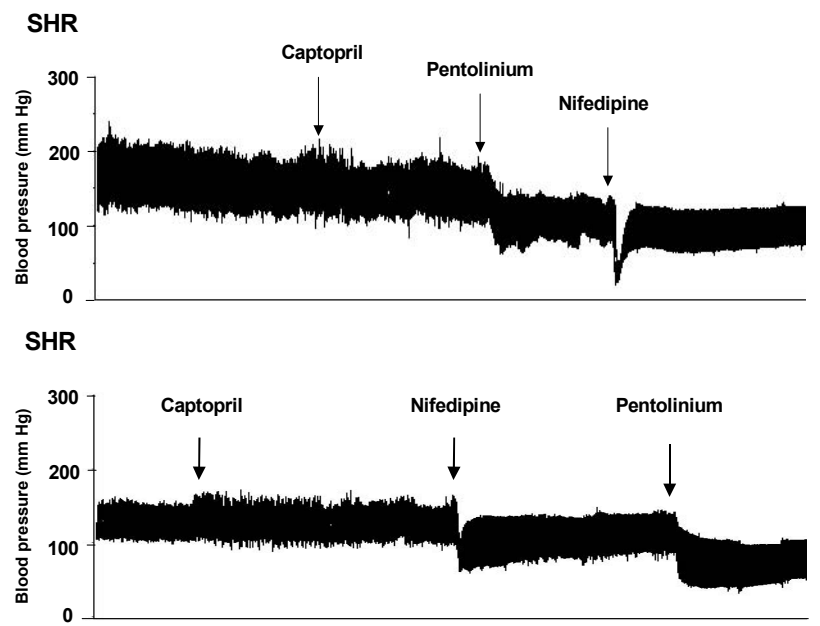

Fig. 7. Time course of $B P$ changes elicited in SHR by the administration of nifedipine $(0.4 \mathrm{mg} / \mathrm{kg}$ i.v.) after (upper panel) or before (lower panel) pentolinium injection $(5 \mathrm{mg} / \mathrm{kg}$ i.v.).
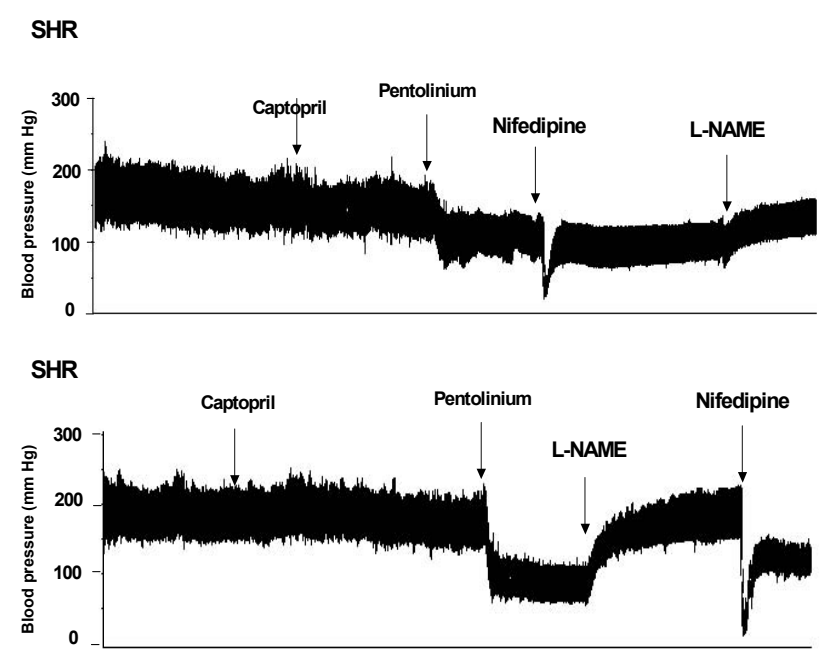

Fig. 8. Time course of $B P$ changes elicited in SHR by the administration of nifedipine ( $0.4 \mathrm{mg} / \mathrm{kg}$ i.v.) before (upper panel) or after (lower panel) L-NAME injection ( $30 \mathrm{mg} / \mathrm{kg}$ i.v.).

\section{Vasoactive system dysbalance and aug- mented nifedipine-sensitive $\mathrm{Ca}^{2+}$ influx}

Our recent effort was focused to the elucidation of 1) the contribution of vasoconstrictor and vasodilator systems to enhanced nifedipine-sensitive $\mathrm{Ca}^{2+}$ influx in hypertension, and 2) the mechanisms by which $\mathrm{NE}$ and $\mathrm{NO}$ can control the opening of L-VDCC.

First, we have demonstrated that nifedipinesensitive BP component is a considerable part of sympathetic vasoconstriction represented by pentoliniuminduced BP change (Fig. 7). It is evident that nifedipine has only minimal BP effect in pentolinium-pretreated SHR $(-10 \pm 3 \mathrm{~mm} \mathrm{Hg})$, whereas pentolinium can still lower BP in nifedipine-pretreated rats $(-49 \pm 7 \mathrm{~mm} \mathrm{Hg})$. Figure 8 shows that $\mathrm{Ca}^{2+}$ influx through L-VDCC is modulated by endogenous NO which closes L-VDCC. Nifedipine considerably attenuates BP rise occurring after L-NAME injection (39\% of BP change observed prior to nifedipine injection to SHR) (Fig. 8, upper panel) and it also rapidly abolishes the already developed BP elevation elicited by acute L-NAME injection (BP decreased by $87 \%$ ) (Fig. 8, lower panel).

Thus enhanced NE stimulation or diminished NO availability can effectively raise blood pressure within a broad range through a modulation of nifedipine-sensitive $\mathrm{Ca}^{2+}$ influx. It should be mentioned that vasodepressor role of NO can be partially replaced by EDHF in certain forms of hypertension characterized by pronounced $\mathrm{NO}$ deficiency (e.g. after chronic L-NAME administration). EDHF participation in these animals can be revealed by the administration of tetraethylammonium (TEA) which in concentrations up to $1 \mathrm{mM}$ blocks $\mathrm{Ca}^{2+}$-activated potassium channels $\left(\mathrm{BK}_{\mathrm{Ca}}\right.$ ) (Fig. 9) (Zicha et al. 2006a). 


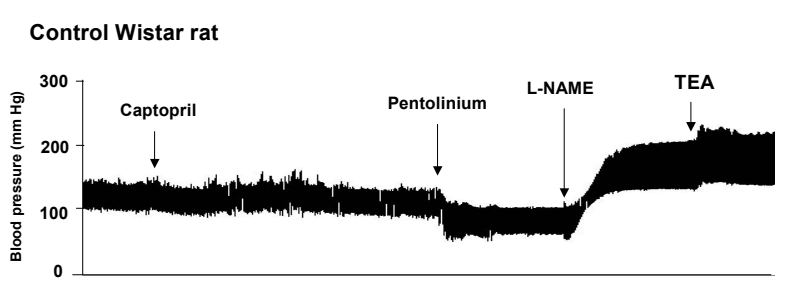

L-NAME-treated rat

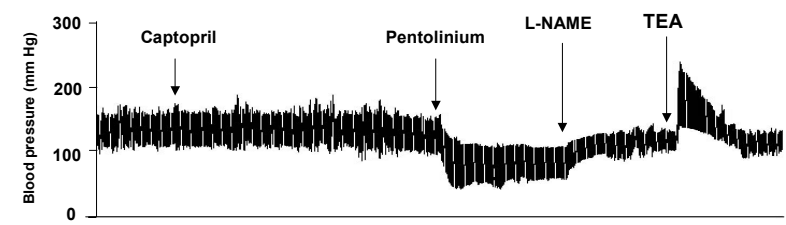

Fig. 9. Time course of BP changes elicited by tetraethylammonium (TEA, $15 \mathrm{mg} / \mathrm{kg}$ i.v.) in control (upper panel) and chronically L-NAME-treated Wistar rat (lower panel).

Nevertheless, our further experiments indicated that $\mathrm{Ca}^{2+}$-activated potassium channels are controlled not only by EDHF but also by NO. BP elevation elicited by TEA injection in conscious captopril- and pentoliniumpretreated rats was considerably greater if TEA was administered prior to the inhibition of NO synthase (NOS) than following NOS inhibition ( $+54 \pm 6$ vs. $86 \pm 3$ $\mathrm{mm} \mathrm{Hg}$ ), although the combination of both drugs elicited similar BP rise irrespective of drug sequence $(+104 \pm 5 \mathrm{vs}$. $98 \pm 3 \mathrm{~mm} \mathrm{Hg}$ ) (Dobešová et al., unpublished data). Similar relationship was also demonstrated in isolated femoral arteries (Líšková et al., unpublished data). Our results are in agreement with the proposal of complementary participation of NO and EDHF in vascular relaxation (Bauersachs et al. 1996, Fleming et al. 1996) when lowering of NO production enhances the influence of EDHF on $\mathrm{Ca}^{2+}$-activated potassium channels in order to achieve sufficient membrane hyperpolarization. This replacement of vasodilator role of NO by EDHF is more pronounced after chronic than acute NOS inhibition (Gerová 1999, Desai et al. 2006). The importance of EDHF replacing the missing NO was further demonstrated in eNOS knockout mice (Waldron et al. 1999, Huang et al. 2000, Brandes et al. 2000, Scotland et al. 2005, Lidington et al. 2007).

\section{The role of inhibitory $G$ proteins in the control of $L-V D C C$}

We have paid a lot of attention to the possible mechanisms by which noradrenergic stimulation can cause nifedipine-sensitive tonic vascular contraction. A part of our effort was directed to the pathways involving inhibitory $G\left(G_{i}\right)$ proteins. Figure 4 indicates that NE can bind to distinct alpha-adrenoceptors and activate $\mathrm{G}_{\mathrm{i}}$ protein pathway, leading thus to the attenuation of cAMP formation. We therefore used in vivo administration of pertussis toxin (PTX) for long-term $G_{i}$ protein inactivation (Líšková et al. 2007, Zemančíková et al. 2008, Čačányiová et al. 2008, Pintérová et al. 2006, 2007a,b, Zicha et al. 2006b). PTX pretreatment attenuated NE-induced contractile response of isolated arteries. In the presence of nifedipine there was no difference in in vitro contractile response to NE between femoral arteries isolated from intact or PTX-treated Wistar rats (Líšková et al. 2007). Moderate attenuation of contractile response to exogenous or endogenous NE was also observed in aorta or mesenteric artery of PTXtreated SHR (Zemančíková et al. 2008).
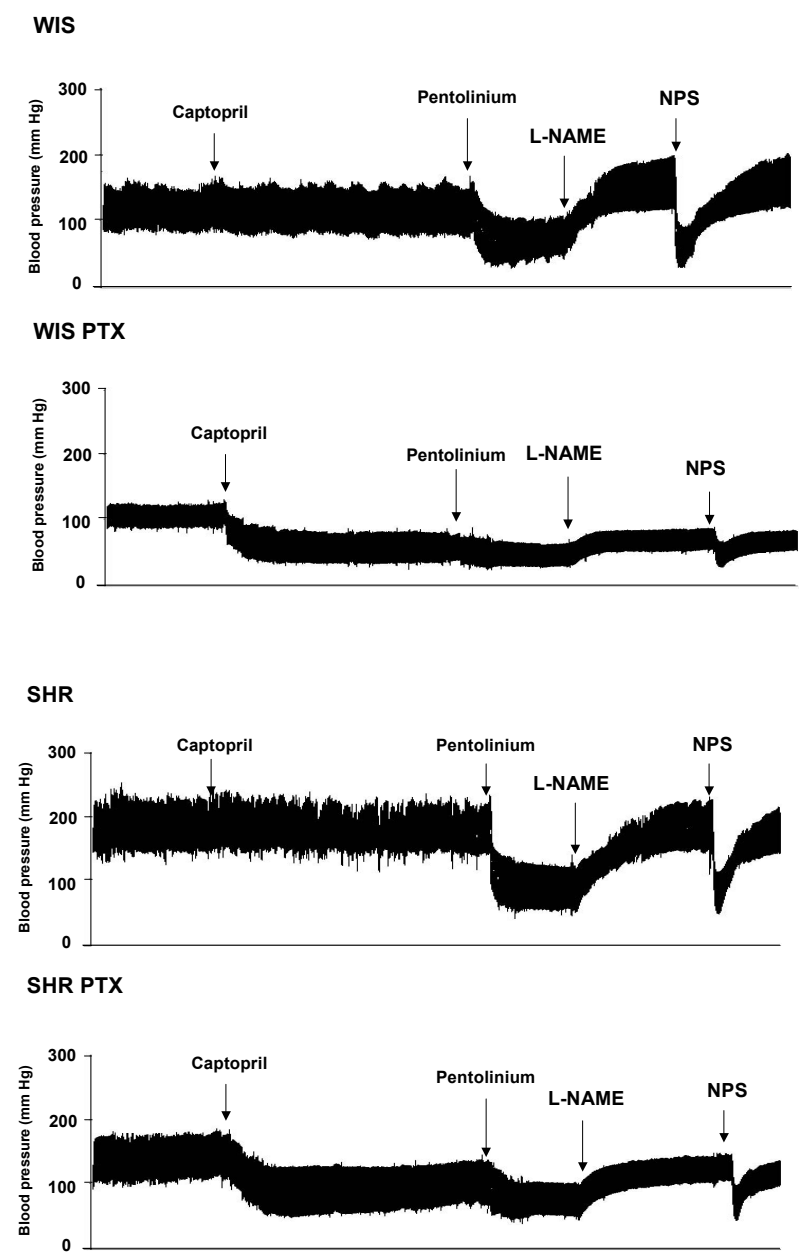

Fig. 10. Time course of BP changes induced by sequential blockade of renin-angiotensin system (captopril, $10 \mathrm{mg} / \mathrm{kg}$ i.v.), sympathetic nervous system (pentolinium, $5 \mathrm{mg} / \mathrm{kg}$ i.v.) and NO synthase (L-NAME, $30 \mathrm{mg} / \mathrm{kg}$ i.v.) in Wistar (WIS), PTX-treated Wistar, SHR and PTX-treated SHR animals. NPS - sodium nitroprusside. 
Table 1. Blood pressure changes induced by acute administration of ganglionic blocker pentolinium (5 mg/kg i.v.) or ACE inhibitor captopril $(10 \mathrm{mg} / \mathrm{kg}$ i.v.) to 14-week-old spontaneously hypertensive rats (SHR) and normotensive Wistar rats (WIS) before or three days after the treatment with pertussis toxin (PTX, $10 \mu \mathrm{g} / \mathrm{kg}$ i.v.).

\begin{tabular}{lllll}
\hline Drug & \multicolumn{3}{c}{ BP change $(\mathbf{m m ~ H g})$} & BP change (mm Hg) \\
\hline Pentolinium & SHR & $-82.4 \pm 4.4$ & WIS & $-44.4 \pm 2.8^{*}$ \\
& SHR-PTX & $-16.6 \pm 1.7 \#$ & WIS-PTX & $-14.4 \pm 2.2 \#$ \\
Captopril & SHR & $-3.5 \pm 2.2$ & WIS & $-5.9 \pm 2.4$ \\
& SHR-PTX & $-42.4 \pm 2.6 \#$ & WIS-PTX & $-36.0 \pm 4.6 \#$ \\
\hline
\end{tabular}

Data are means \pm S.E.M. $(n=6-8)$. Significantly different $(p<0.05): *$ from SHR, \# from intact animals untreated with PTX.

It is evident from Figure 10 that in both SHR and Wistar rats PTX pretreatment considerably diminished BP reduction elicited by pentolinium injection (Table 1). The missing noradrenergic vasoconstriction was replaced by substantial activation of circulating angiotensin II as evidenced by a rapid pronounced BP fall after acute captopril administration (Fig. 10, Table 1) (Zicha et al. 2006b). Our further in vivo experiments indicated that chronic $\mathrm{G}_{\mathrm{i}}$ protein inactivation substantially attenuated BP response to exogenous NE, shifting the respective dose-response curve to the right by at least one order of magnitude. PTX-induced changes were similar to the effects of acute nifedipine administration (Pintérová et al. 2007c).

In these experiments we have also noticed that PTX pretreatment caused a considerable attenuation of LNAME induced BP rise which was present especially in Wistar rats. The attenuation of BP response to acute NO deficiency in PTX-treated rats was further supported by their diminished BP lowering response to NO donor (sodium nitroprusside) administered during acute NOS inhibition (Fig. 10). The finding of attenuated BP response to L-NAME in PTX-pretreated rats suggested an interesting hypothesis according to which the enhanced cAMP production (due to inactivation of $\mathrm{G}_{\mathrm{i}}$ protein pathway) might diminish $\mathrm{Ca}^{2+}$ influx elicited by the absence of cGMP following acute NOS inhibition. To evaluate this hypothesis we have performed some experiments on Wistar rats in which cAMP level was increased by isoprenaline infusion ( $\beta$-adrenoceptor agonist) or decreased by propranolol administration ( $\beta$ adrenoceptor antagonist). Figure 11 documents that increased cAMP formation following isoprenaline infusion almost abolished BP response to L-NAME and this BP response was normalized by propranolol injection, although isoprenaline infusion continued. It is also evident that $\beta$-adrenoceptor blockade not only permitted BP rise elicited by cGMP deficiency but also restored the sensitivity of BP of NO-deficient rats to sodium nitroprusside injection (Fig. 11). Thus cyclic nucleotides (both cAMP and cGMP) are involved in the control of $\mathrm{Ca}^{2+}$ influx by inhibiting the permeability of L-VDCC for $\mathrm{Ca}^{2+}$ ions (Pintérová et al. 2009a,b).

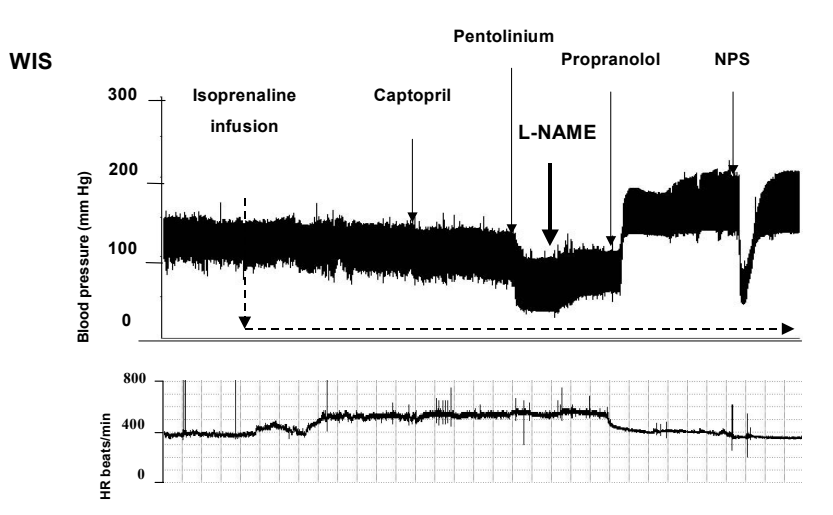

Fig. 11. The effect of $\beta$-adrenoceptor agonist isoprenaline infusion (100 $\mathrm{ng} / \mathrm{kg} / \mathrm{min}$ i.v.) on L-NAME-induced BP changes in Wistar rat and the restoration of L-NAME-induced BP rise by injection of $\beta$-adrenoceptor antagonist propranolol ( $1 \mathrm{mg} / \mathrm{kg}$ i.v.).

However, there must be additional mechanism(s) controlling the opening of L-VDCC in the absence of cyclic nucleotides. Such mechanism(s) might be important for the maintenance of high BP because SHR had elevated BP compared to Wistar rats even if they were subjected to acute combined blockade of RAS, SNS and NOS (MAP: $180 \pm 4$ vs. $116 \pm 9 \mathrm{~mm} \mathrm{Hg}, \mathrm{p}<0.001$ ), i.e. under the conditions when both cGMP and cAMP levels are expected to be low. This BP difference was almost entirely dependent upon $\mathrm{Ca}^{2+}$ influx through L-VDCC because it was minimized by acute nifedipine administration $(99 \pm 6$ vs. $83 \pm 5 \mathrm{~mm} \mathrm{Hg}, \mathrm{p}<0.10)$ which lowered BP substantially more in SHR than in Wistar rats ( $-80 \pm 8$ vs. $-33 \pm 10 \mathrm{~mm} \mathrm{Hg}, \mathrm{p}<0.001)$. The mechanisms 
underlying different L-VDCC opening in genetically hypertensive and normotensive rats remain to be investigated.

\section{The contribution of $\alpha_{2}$ - and $\alpha_{1}$-adrenoceptors to NE-induced stimulation of $\mathrm{Ca}^{2+}$ influx}

Our attention was also focused on the role of particular $\alpha$-adrenoceptors because we wanted to distinguish the contribution of $\alpha_{2}$-and $\alpha_{1}$-adrenoceptors to NE-stimulated $\mathrm{Ca}^{2+}$ influx through L-VDCC (Fig. 4). Previous studies (van Meel et al. 1983, Kazda et al. 1985) indicated a greater impact of calcium antagonists on $\alpha_{2}$ - than on $\alpha_{1}$-adrenergic vasoconstriction and this effects was even more pronounced in SHR compared to Wistar-Kyoto (WKY) rats. Our preliminary in vitro experiments carried out in femoral arteries isolated from SHR (Líšková et al., unpublished data) revealed major differences in the effects of L-VDCC closure (following nifedipine administration or PTX treatment) on the contraction elicited either by $\alpha_{2}$ or $\alpha_{1}$-adrenoceptor agonists (clonidine or phenylephrine) (Fig. 12).

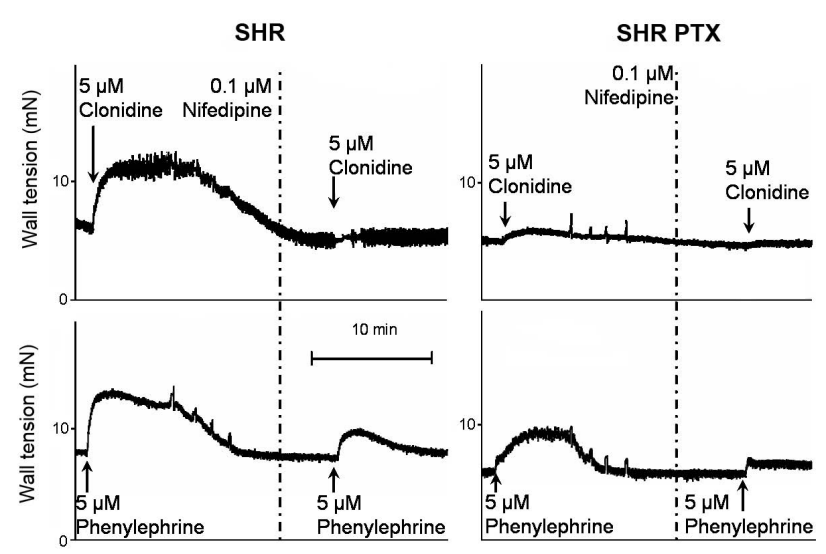

Fig. 12. The effect of nifedipine (NIF) on the contraction elicited by $\mathrm{a}_{2}$-adrenoceptor agonist clonidine (upper panels) or $\mathrm{a}_{1}$ adrenoceptor agonist phenylephrine (lower panels) in deendothelized femoral arteries isolated from control SHR (left panels) and SHR pretreated with pertussis toxin $(20 \mu \mathrm{g} / \mathrm{kg}$ i.v. 3 days before) (PTX SHR, right panels).

Clonidine-induced contraction was abolished not only by nifedipine presence in the incubation medium but also by PTX pretreatment (Fig. 12, upper panels). This indicates that $\alpha_{2}$-adrenergic vasoconstriction is entirely based upon $\mathrm{Ca}^{2+}$ influx through L-VDCC which can be closed either by dihydropyridine antagonist nifedipine or following PTX-induced inactivation of $\mathrm{Gi}$ proteins through cAMP-mediated mechanisms (see above). On the other hand, phenylephrine-induced contraction was only attenuated by nifedipine or PTX, but the combination of these two interventions minimized contractile response elicited by phenylephrine (Fig. 12, lower panels). Although in vivo determined NE dose-response curves were very similar in SHR and WKY rats and nifedipine shifted these curves to the right in both rat strains (Pintérová et al. 2007c), there might be considerable differences in $\alpha_{1}$ - and $\alpha_{2}$-adrenergic components of NEinduced BP responses. We therefore determined $\mathrm{NE}$ dose-response curves in the presence of $\alpha_{1-}$ or $\alpha_{2}$ adrenoceptor antagonists (prazosin or yohimbine), which preserved selective $\alpha_{2}$ - or $\alpha_{1}$-adrenergic components of BP response to NE (Behuliak et al. 2009).

Figure 13 shows that prazosin but not yohimbine lowered maximal BP response to $\mathrm{NE}$ in both strains suggesting a generally greater importance of $\alpha_{1}$ - than $\alpha_{2}$ adrenergic vasoconstriction for BP response to NE. This is especially true in normotensive WKY rats, whereas the ratio between $\alpha_{1}$ - and $\alpha_{2}$-adrenergic components of BP response to NE was reduced in SHR. In fact, the effect of yohimbine (rightward shift of NE dose-response curve) was more pronounced in SHR than in WKY rats, indicating that $\alpha_{2}$-adrenergic vasoconstriction might be enhanced in genetic hypertension. This is also in agreement with lower maximal BP response to NE seen in WKY pretreated with $\alpha_{1}$-adrenoceptor antagonist prazosin. It should also be noted that both $\alpha_{1}$ - and $\alpha_{2}$ adrenoceptor antagonists reduced considerably the sensitivity of SHR to NE (increased $\mathrm{ED}_{50}$ ), but these changes were absent in WKY rats (Fig. 13). The reasons for these strain-dependent changes in NE sensitivity remain to be elucidated.

Our further investigations revealed that in both rat strains acute nifedipine administration lowered the sensitivity to NE by one order of concentration without significant changes in maximal BP response to NE (Fig. 14, upper panels). Similar nifedipine effect was also observed when $\alpha_{1}$-adrenergic vasoconstriction was studied (in the presence of $\alpha_{2}$-adrenoceptor blocker yohimbine) (Fig. 14, lower panels). On the other hand, nifedipine lowered not only sensitivity to NE but also maximal BP response to NE (more in SHR than WKY) if we studied $\alpha_{2}$-adrenergic vasoconstriction (in the presence of $\alpha_{1}$-adrenoceptor blocker prazosin) (Fig. 14, middle panels). The above data confirm considerable importance of $\alpha_{2}$-adrenergic vasoconstriction in SHR as it was previously suggested by Kazda et al. (1985), Pettinger et al. (1982), Sanchez et al. (1986) and others. 

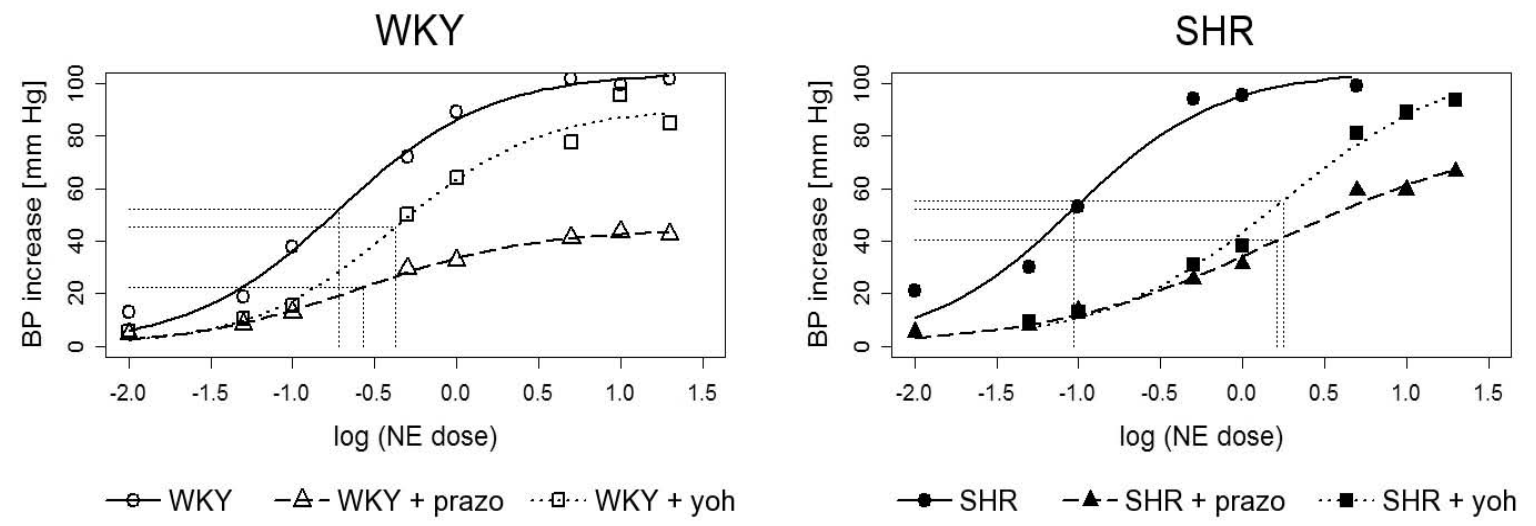

Fig. 13. The dose-response curves constructed from BP responses to NE recorded in conscious WKY (left panel) and SHR (right panel) rats pretreated with captopril (10 mg/kg i.v.) and pentolinium $(5 \mathrm{mg} / \mathrm{kg}$ i.v.). NE dose-response curves were also determined in the presence of antagonists of either $a_{1}$ - or $a_{2}$-adrenoceptors (prazosin or yohimbine, $1 \mathrm{mg} / \mathrm{kg}$ i.v. each). Thin dotted lines indicate halfmaximal BP response $(\mathrm{mm} \mathrm{Hg})$ and $\mathrm{ED}_{50}$ (log NE dose).
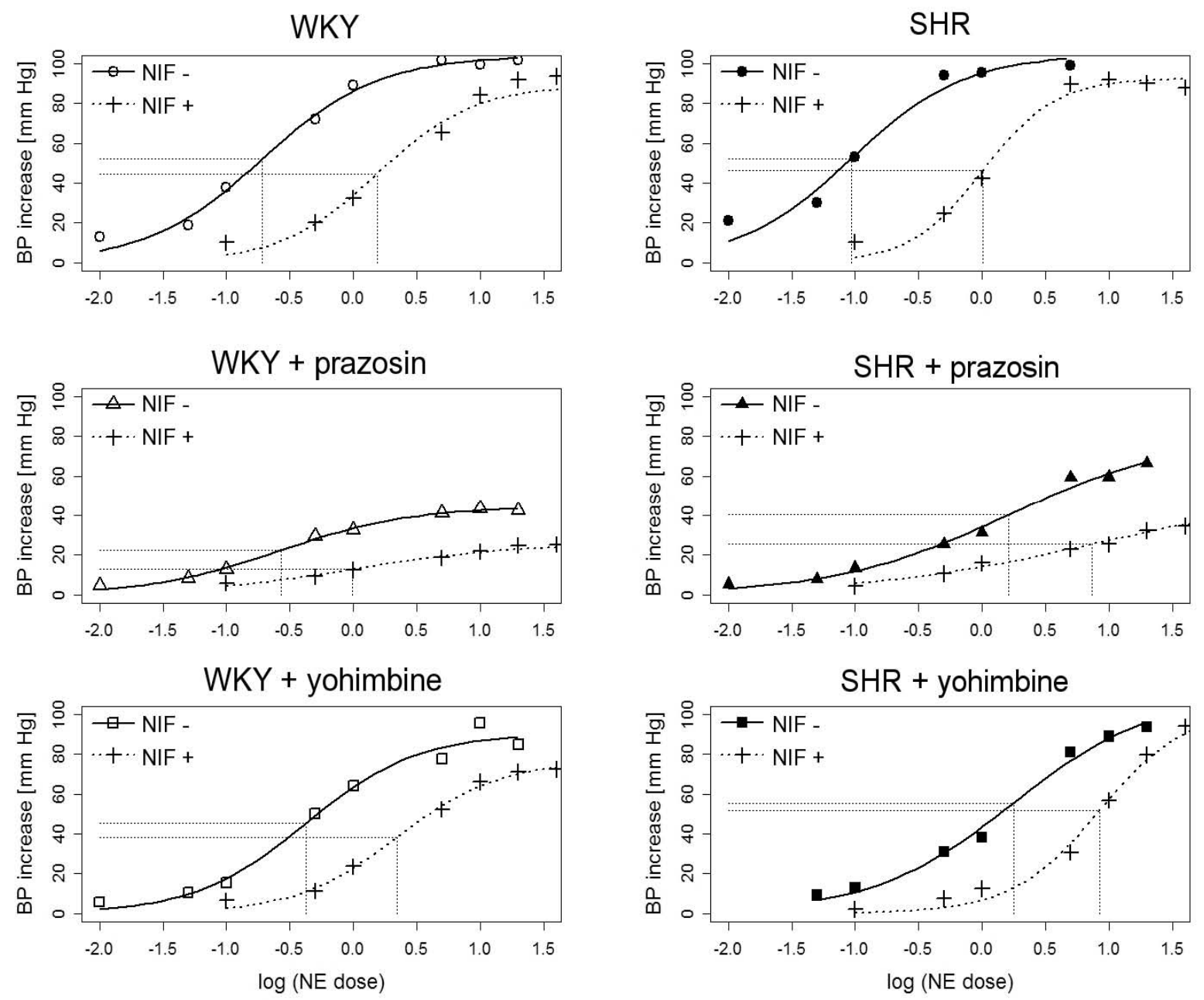

Fig. 14. The influence of acute nifedipine administration $(0.4 \mathrm{mg} / \mathrm{kg}$. i.v.) on NE dose-response curves measured in conscious WKY (left panels) and SHR (right panels) rats pretreated with captopril and pentolinium. NE dose-response curves were also determined in the presence of prazosin (middle panels) or yohimbine (lower panels) to evaluate $a_{2}$ - or $a_{1}$-adrenergic components of BP response to NE. 


\section{EDCF and $\mathrm{Ca}^{2+}$-activated $\mathrm{Cl}^{-}$channels - open chapters in hypertension research}

It remains an open question whether cyclic nucleotides influence L-VDCC directly or indirectly through the modulation of $\mathrm{Ca}^{2+}$-activated $\mathrm{K}^{+}$and $\mathrm{Cl}^{-}$ channels resulting in membrane potential changes (Fig. 4). Major augmentation of $\mathrm{Ca}^{2+}$-activated $\mathrm{K}^{+}$and $\mathrm{Cl}^{-}$ transport in arteries of rats with various forms of experimental hypertension was already described more than 30 years ago (Jones 1974). There is some evidence that NO and/or EDHF can enhance the activity of $\mathrm{Ca}^{2+}$ activated $\mathrm{K}^{+}$channels leading thus to membrane hyperpolarization. On the other hand, there is only scarce information on the role and control of $\mathrm{Ca}^{2+}$-activated $\mathrm{Cl}^{-}$ channels the activation of which may lead to membrane depolarization and $\mathrm{Ca}^{2+}$ influx through L-VDCC (Jackson 2000). Our recent observations point to a quite interesting relationship between NE-induced vasoconstriction and the so called endothelium-derived contracting factor (EDCF), which seems to be prostaglandin $\mathrm{H}_{2}$ acting on thromboxane-prostanoid (TP) receptors of the vascular smooth muscle (Vanhoutte et al. 2005, Vanhoutte and Tang 2008). The role of EDCF in different forms of experimental hypertension is largely unknown, although its presence has been demonstrated in genetic hypertension of SHR (Lüscher and Vanjhoutte 1986, Rapoport and Williams 1996), salt hypertension of Dahl rats (Zhu et al. 1999, Zhou et al. 2001) and NO-deficient hypertension of L-NAME-treated rats (Zanchi et al. 1995, Paulis et al. 2008).

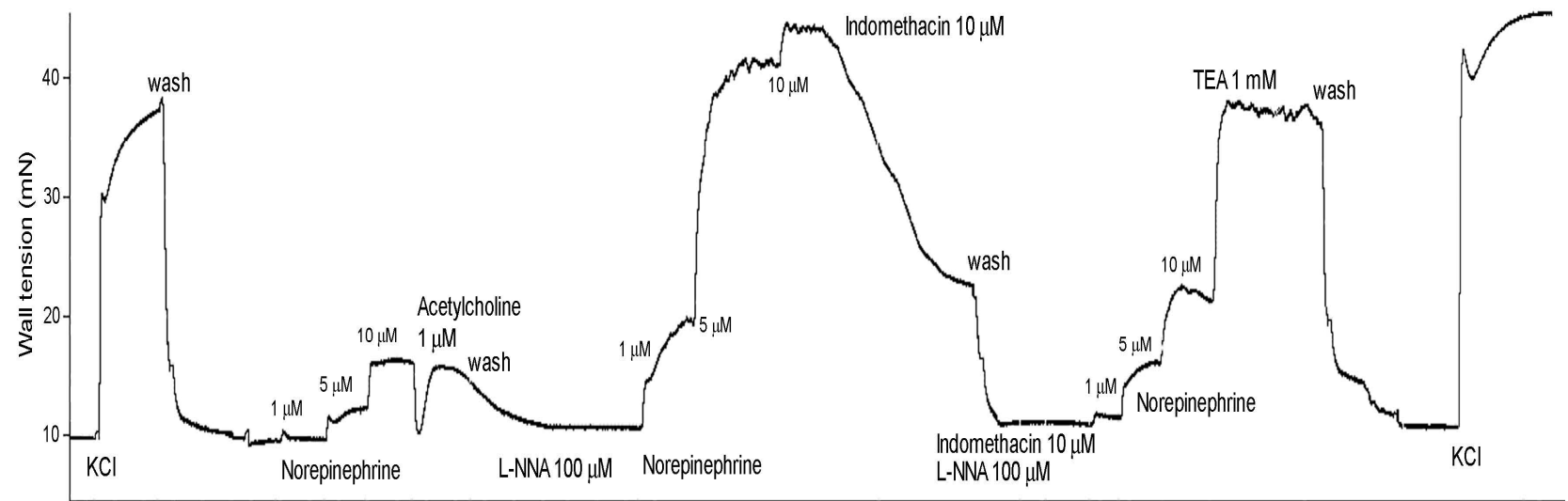

Fig. 15. NE dose-response determined in isolated femoral artery prior to and after $L-N^{G}$-nitro-L-arginine addition (L-NNA, $\left.100 \mu m o l / I\right)$. Note the therapeutic effect of indomethacin $(10 \mu \mathrm{mol} / \mathrm{l})$ when added to the already developed contraction as well as its preventive effect when applied prior to NE. The blockade of $\mathrm{Ca}^{2+}$-activated $\mathrm{K}^{+}$channels by tetraethylammonium (TEA, $\left.1 \mathrm{mmol} / \mathrm{l}\right)$ fully restored the augmented contractile response to NE (seen after NO synthase blockade by L-NNA).

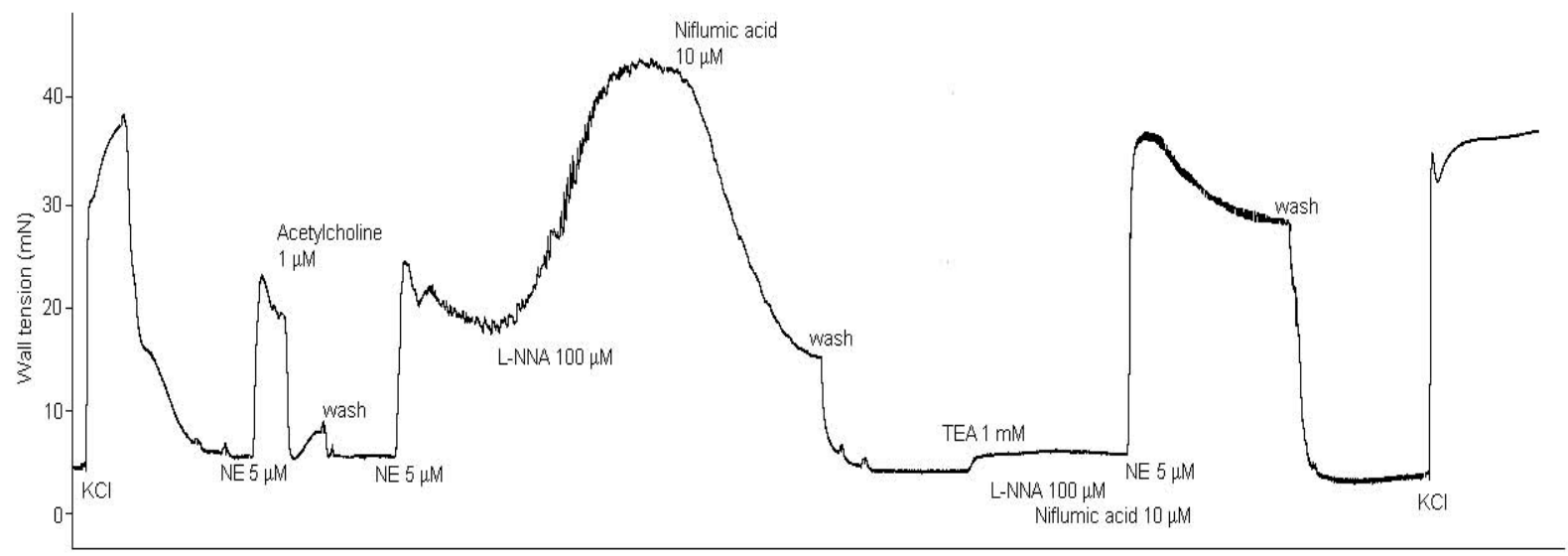

Fig. 16. The therapeutic and preventive effects of niflumic acid $(10 \mu \mathrm{mol} / \mathrm{l})$ on NE-induced contraction of femoral artery pretreated with L-NNA $(100 \mu \mathrm{mol} / \mathrm{l})$. Note that the addition of tetraethylammonium (TEA, $1 \mathrm{mmol} / \mathrm{l})$ almost fully restored contractile response to NE attenuated by niflumic acid. 
Figure 15 shows that under the conditions of NO deficiency a major part of NE-induced contraction of isolated femoral artery can be prevented by cyclooxygenase inhibitors (e.g. indomethacin). It seems that not only high doses of acetylcholine (Lüscher and Vanhoutte 1986, Koga et al. 1989, Watt and Thurston 1989) but also high NE doses augment the production of EDCF in rat conduit arteries. It is important to note that indomethacin does not only prevent NE-induced arterial contraction but can also rapidly abolish the already developed contraction (Fig. 15). The extent of this indomethacin-induced reduction of vascular wall tension is comparable to the effects of nifedipine. Similar effects on vascular wall tension of NE-precontracted artery can also be achieved by the addition of niflumic acid (Fig. 16). Niflumic acid is another cyclooxygenase inhibitor which was, however, reported to block $\mathrm{Ca}^{2+}$ activated $\mathrm{Cl}^{-}$channels (Criddle et al. 1997, He and Tabrizchi 1997). Our recent data suggest that the relaxing effects of both indomethacin and niflumic acid result from the closure of L-VDCC which is parallel to the activation of $\mathrm{Ca}^{2+}$-activated $\mathrm{K}^{+}$channels, because the blockade of these channels by TEA fully restores the contractile response to NE even in the presence of COX inhibitors (Fig. 16) (Líšková et al. 2009). Although we do not know whether the above mechanism is also pertinent to small resistance vessels, the extent of EDCF contribution to NE-induced arterial contraction as well as the possible relationship of EDCF to the control of LVDCC make this research topic highly attractive.

\section{Conclusions}

To elucidate the above abnormalities in hypertensive rats our future research should be focused on detailed mechanisms by which cyclic nucleotides modify the opening of L-VDCC, and to the role exerted by calcium-activated $\mathrm{K}^{+}$and $\mathrm{Cl}^{-}$channels in the control of membrane potential responsible for L-VDCC opening. Another important issue will be the role of endotheliumderived contracting factor in adrenergic vasoconstriction as well as the possible relation of this factor to the control of calcium-activated $\mathrm{Cl}^{-}$channels.

\section{Conflict of Interest}

There is no conflict of interest.

\section{Acknowledgements}

The experimental work described in this review has been partially supported by AV0Z 50110509, and research grants of GA CR 305/08/0139 and 305/09/0336, IGA AV CR IAA500110902 and 1M0510 (Ministry of Education of the Czech Republic).

\section{References}

BAUERSACHS J, POPP R, HECKER M, SAUER E, FLEMING I, BUSSE R: Nitric oxide attenuates the release of endothelium-derived hyperpolarizing factor. Circulation 94: 3341-3347, 1996.

BEHULIAK M, PINTÉROVÁ M, KUNEŠ J, ZICHA J: Different contribution of alpha-1- and alpha-2-adrenergic vasoconstriction to pressor effects of exogenous norepinephrine in WKY and SHR rats (abstract). J Hypertens in press 2009.

BRANDES RP, SCHMITZ-WINNENTHAL FH, FÉLÉTOU M, GÖDECKE A, HUANG PL, VANHOUTTE PM, FLEMING I, BUSSE R: An endothelium-derived hyperpolarizing factor distinct from NO and prostacyclin is a major endothelium-dependent vasodilator in resistance vessels of wild-type and endothelial NO synthase knockout mice. Proc Natl Acad Sci USA 97: 9747-9752, 2000.

ČAČÁNYIOVÁ S, KRISTEK F, KUNEŠ J, ZICHA J: The effects of pertussis toxin-treatment on integrated vasoactive response of vascular system in spontaneously hypertensive rats. Physiol Res 57: 137-139, 2008.

CRIDDLE DN, SOARES DE MOURA R, GREENWOOD IA, LARGE WA: Inhibitory action of niflumic acid on noradrenaline- and 5-hydroxytryptamine-induced pressor responses in the isolated mesenteric vascular bed of the rat. Br J Pharmacol 120: 813-818, 1997.

DESAI KM, GOPALAKRISHNAN V, HIEBERT LM, MCNEILL JR, WILSON TW: EDHF-mediated rapid restoration of hypotensive response to acetylcholine after chronic, but not acute, nitric oxide synthase inhibition in rats. Eur J Pharmacol 546: 120-126, 2006.

DOBEŠOVÁ Z, KUNEŠ J, ZICHA J: The altered balance between sympathetic nervous system and nitric oxide in salt hypertensive Dahl rats: ontogenetic and $\mathrm{F}_{2}$ hybrid studies. J Hypertens 20: 945-955, 2002. 
FLEMMING I, BAUERSACHS J, BUSSE R: Paracrine functions of the coronary vascular endothelium. Mol Cell Biochem 157: 137-145, 1996.

GEROVÁ M: Acetylcholine and bradykinin induce paradoxically amplified hypotensive response in hypertensive NOdeficient rats. Physiol Res 48: 249-257, 1999.

HE Y, TABRIZCHI R: Effects of niflumic acid on 1-adrenoceptor-induced vasoconstriction in mesenteric artery in vitro and in vivo in two-kidney one-clip hypertensive rats. Eur J Pharmacol 328: 191-199, 1997.

HUANG A, SUN D, SMITH CJ, CONNETTA JA, SHESELY EG, KOLLER A, KALEY G: In eNOS knockout mice skeletal muscle arteriolar dilation to acetylcholine is mediated by EDHF. Am J Physiol 278: H762-H768, 2000.

HOJNÁ S, KADLECOVÁ M, DOBEŠOVÁ Z, VALOUŠKOVÁ V, ZICHA J, KUNEŠ J: The participation of brain NO synthase in blood pressure control of adult spontaneously hypertensive rats. Mol Cell Biochem 297: 21-29, 2007.

JACKSON WF: Ion channels and vascular function. Hypertension 35: 173-178, 2000.

JONES AW: Reactivity of ion fluxes in rat aorta during hypertension and circulatory control. Fed Proc 33: 133-137, 1974.

KAZDA S, GARTHOFF B, KNORR A: There is some evidence that NO and/or EDHF can enhance the activity of $\mathrm{Ca}^{2+}$-activated $\mathrm{K}^{+}$channels leading thus to membrane hyperpolarization. J Cardiovasc Pharmacol 7 (Suppl 6): S61-S65, 1985.

KOGA T, TAKATA Y, KOBAYASHI K, TAKISHITA S, YAMASHITA Y, FUJISHIMA M: Age and hypertension promote endothelium-dependent contractions to acetylcholine in the aorta of the rat. Hypertension 14: 542-548, 1989.

KUNEŠ J, DOBEŠOVÁ Z, ZICHA J: Altered balance of main vasopressor and vasodepressor systems in rats with genetic hypertension and hypertriglyceridaemia. Clin Sci 102: 269-277, 2002.

KUNEŠ J, HOJNÁ S, KADLECOVÁ M, DOBEŠOVÁ Z, RAUCHOVÁ H, VOKURKOVÁ M, LOUKOTOVÁ J, PECHÁŇOVÁ O, ZICHA J: Altered balance of vasoactive systems in experimental hypertension: the role of relative NO deficiency. Physiol Res 53 (Suppl 1): S23-S34, 2004.

KUNEŠ J, DOBEŠOVÁ Z, MUSILOVÁ A, ZÍDEK V, VORLÍČEK J, PRAVENEC M, KŘEN V, ZICHA J: Hemodynamic characterization of recombinant inbred strains: 20 years after. Hypertens Res 31: 1659-1668, 2008.

LIDINGTON D, LI F, TYML K: Deletion of neuronal NOS prevents impaired vasodilation in septic mouse skeletal muscle. Cardiovasc Res 74: 151-158, 2007.

LÍŠKOVÁ S, ZICHA J, KUNEŠ J: Nifedipine-sensitive vascular reactivity of femoral arteries in WKY: the effect of pertussis toxin pretreatment and endothelium removal. Physiol Res 56: 663-666, 2007.

LÍŠKOVÁ S, KUNEŠ J, ZICHA J: Attenuation of norepinephrine-induced vascular contraction by acute inhibition of cyclooxygenase: the role of $\mathrm{Ca}^{2+}$-activated $\mathrm{K}^{+}$and $\mathrm{Cl}^{-}$channels (abstract). Hypertension in press 2009.

LÜSCHER TF, VANHOUTTE PM: Endothelium-dependent vascular contractions to acetylcholine in the aorta of the spontaneously hypertensive rat. Hypertension 8: 344-348, 1986.

PAULIS L, LÍŠKOVÁ S, PINTÉROVÁ M, DOBEŠOVÁ Z, KUNEŠ J, ZICHA J: Nifedipine-sensitive noradrenergic vasoconstriction is enhanced in spontaneously hypertensive rats: the influence of chronic captopril treatment. Acta Physiol (Oxford) 191: 255-266, 2007.

PAULIS L, ZICHA J, KUNEŠ J, HOJNÁ S, BEHULIAK M, CELEC P, KOJŠOVÁ S, PECHÁŇOVÁ O, ŠIMKO F: Regression of L-NAME-induced hypertension: the role of nitric oxide and endothelium-derived constricting factor. Hypertens Res 31: 793-803, 2008.

PECHÁŇOVÁ O, DOBEŠOVÁ Z, ČEJKA J, KUNEŠ J, ZICHA J: Vasoactive systems in L-NAME hypertension: the role of inducible NO synthase. J Hypertens 22: 167-173, 2004.

PETTINGER WA, SANCHEZ A, SAAVEDRA J, HAYWOOD JR, GANDLER T, RODES T: Altered renal $\alpha_{2}-$ adrenergic receptor regulation in genetically hypertensive rats. Hypertension 4: 188-192, 1982.

PINTÉROVÁ M, KUNEŠ J, DOBEŠOVÁ Z, ZICHA J: The role of $\mathrm{Ca}^{2+}$ influx and Gi proteins in $\alpha_{1}$ - and $\alpha_{2}$-adrenergic vasoconstriction elicited in SHR and WKY rats. Hypertension 48: 769, 2006.

PINTÉROVÁ M, KUNEŠ J, DOBEŠOVÁ Z, ZICHA J: Calcium influx and alpha-adrenergic vasoconstriction in SHR and WKY rats: the role of voltage-dependent calcium channels and inhibitory G proteins. J Hypertens 25 (Suppl 2): S22-S23, 2007a. 
PINTÉROVÁ M, KUNEŠ J, DOBEŠOVÁ Z, ZICHA J: In vivo effects of pertussis toxin on adrenergic vasoconstriction. In: Nitric Oxide Signaling Pathways, O. PECHÁŇOVÁ (ed), Advent-Orion, Bratislava, 2007b, pp 76-82.

PINTÉROVÁ M, KUNEŠ J, DOBEŠOVÁ Z, ZICHA J: Nifedipine-induced shift of norepinephrine dose-response curve is similar in resistance vasculature of conscious SHR and WKY rats. Hypertension 50: 812, 2007c.

PINTÉROVÁ M, BEHULIAK M, KUNEŠ J, ZICHA J: Beta-adrenergic vasodilation of isoprenaline is largely prevented by endogenous nitric oxide in conscious Wistar but not in SHR rats (abstract). $J$ Hypertens 27 (Suppl 4): S298-S299, 2009a.

PINTÉROVÁ M, BEHULIAK M, KUNEŠ J, ZICHA J: Influence of beta-adrenergic stimulation by isoprenaline on blood pressure and its changes following acute NO synthase blockade: synergic roles of cyclic nucleotides in vasodilation (abstract). Hypertension 54: 1186, 2009b.

RAPOPORT RM, WILLIAMS SP: Role of prostaglandins in acetylcholine-induced contraction of the aorta from spontaneously hypertensive and Wistar-Kyoto rats. Hypertension 28: 64-75, 1996.

SANCHEZ A, VIDAL MJ, MARTÍNEZ-SIERRA R, SÁIZ J: Ontogeny of renal $\alpha_{1}$ and $\alpha_{2}$ adrenoceptors in the spontaneously hypertensive rat. J Pharmacol Exp Ther 237: 972-979, 1986.

SCOTLAND RS, MADHANI M, CHAUHAN S, MONCADA S, ANDRESEN J, NILSSON H, HOBBS AJ, AHLUWALIA A: Investigation of vascular responses in endothelial nitric oxide synthase/cyclooxygenase-1 double-knockout mice: key role for endothelium-derived hyperpolarizing factor in the regulation of blood pressure in vivo. Circulation 111: 796-803, 2005.

VANHOUTTE PM, FELETOU M, TADDEI S: Endothelium-dependent contractions in hypertension. Br J Pharmacol 144: 449-458, 2005.

VANHOUTTE PM, TANG EH: Endothelium-dependent contractions: when a good guy turns bad! J Physiol Lond 586: 5295-5304, 2008.

VAN MEEL JC, TOWART R, KAZDA S, TIMMERMANS PB, VAN ZWIETEN PA: Correlation between the inhibitory activities of calcium entry blockers on vascular smooth muscle constriction in vitro after $\mathrm{K}^{+}$depolarisation and in vivo after $\alpha_{2}$-adrenoceptor stimulation. Naunyn-Schmiedebergs Arch Pharmacol 322: 34$37,1983$.

WALDRON GJ, DING H, LOVREN F, KUBES P, TRIGGLE CR: Acetylcholine-induced relaxation of peripheral arteries isolated from mice lacking endothelial nitric oxide synthase. Br J Pharmacol 128: 653-658, 1999.

WATT PAC, THURSTON H: Endothelium-dependent relaxation in resistance vessels from the spontaneously hypertensive rats. $J$ Hypertens 7: 661-666, 1989.

WU XC, JOHNS E, MICHAEL J, RICHARDS NT: Interdependence of contractile responses of small mesenteric arteries on nitric oxide and cyclo-oxygenase and lipoxygenase products of arachidonic acid. Br J Pharmacol 112: 360-368, 1994.

ZANCHI A, AUBERT JF, BRUNNER HR, WAEBER B: Vascular acetylcholine response during chronic NO synthase inhibition: in vivo versus in vitro. Cardiovasc Res 30: 122-129, 1995.

ZEMANČÍKOVÁ A, TÖRÖK J, ZICHA J, KUNEŠ J: Inactivation of Gi proteins by pertussis toxin diminishes the effectiveness of adrenergic stimuli in conduit arteries from spontaneously hypertensive rats. Physiol Res $\mathbf{5 7}$ : 299-302, 2008.

ZHOU MS, KOSAKA H, TIAN RX, ABE Y, CHEN QH, YONEYAMA H, YAMAMOTO A, ZHANG L: L-Arginine improves endothelial function in renal artery of hypersensitive Dahl rats. $J$ Hypertens 19: 421-429, 2001.

ZHU MS, NISHIDA Y, CHEN QH, KOSAKA H: Endothelium-derived contracting factor in carotid artery of hypertensive Dahl rats. Hypertension 34: 39-43, 1999.

ZICHA J, DOBEŠOVÁ Z, KUNEŠ J: Relative deficiency of nitric oxide-dependent vasodilation in salt hypertensive Dahl rats: the possible role of superoxide anions. J Hypertens 19: 247-254, 2001.

ZICHA J, DOBEŠOVÁ Z, KUNEŠ J: Antihypertensive mechanisms of chronic captopril or N-acetylcysteine treatment in L-NAME hypertensive rats. Hypertens Res 29: 1021-1027, 2006a.

ZICHA J, PINTÉROVÁ M, DOBEŠOVÁ Z, LÍŠKOVÁ S, KUNEŠ J: The effect of pertussis toxin (PTX) treatment on blood pressure (BP), norepinephrine pressor responsiveness and BP response to acute nifedipine administration in genetic hypertension. Hypertension 48: 773-774, $2006 \mathrm{~b}$. 